\title{
NUTRIENT SUPPLY BY MASS FLOW AND DIFFUSION TO MAIZE PLANTS IN RESPONSE TO SOIL AGGREGATE SIZE AND WATER POTENTIAL ${ }^{(1)}$
}

\begin{abstract}
Ermelinda Maria Mota Oliveira ${ }^{(2)}$, Hugo Alberto Ruiz ${ }^{(3)}$,Víctor Hugo Alvarez V. ${ }^{(3)}$, Paulo Afonso Ferreira ${ }^{(4)}$, Fernanda Oliveira Costa ${ }^{(5)}$ \& Ivan Carlos Carreiro Almeida ${ }^{(5)}$

Nutrients are basically transported to the roots by mass flow and diffusion. The aim of this study was to quantify the contribution of these two mechanisms to the acquisition of macronutrients ( N, P, K, Ca, Mg, and S) and cationic micronutrients ( $\mathrm{Fe}, \mathrm{Mn}, \mathrm{Zn}$, and $\mathrm{Cu}$ ) by maize plants as well as xylem exudate volume and composition in response to soil aggregate size and water availability. The experiment was conducted in a greenhouse with samples of an Oxisol, from under two management systems: a region of natural savanna-like vegetation (Cerradão, CER) and continuous maize under conventional management for over 30 years $(C C M)$. The treatments were arranged in a factorial $[2 \times(1+2) \times 2]$ design, with two management systems (CER and CCM), $(1+2)$ soil sifted through a $4 \mathrm{~mm}$ sieve and two aggregate classe $(<0.5 \mathrm{~mm}$ and $0.5-4.0 \mathrm{~mm})$ and two soil matric potentials (-40 and $-10 \mathrm{kPa})$. These were evaluated in a randomized block design with four replications. The experiment was conducted for $\mathbf{7 0}$ days after sowing. The influence of soil aggregate size and water potential on the nutrient transport mechanisms was highest in soil samples with higher nutrient concentrations in solution, in the CER system; diffusion became more relevant when water availability was higher and in aggregates $<0.5 \mathrm{~mm}$. The volume of xylem exudate collected from maize plants increased with the decrease in aggregate size and the increased availability of soil water in the CER system. The highest $\mathrm{Ca}$ and $\mathrm{Mg}$ concentrations in the xylem exudate of plants grown on samples from the CER system were related to the high concentrations of these nutrients in the soil solution of this management system.
\end{abstract}

Index terms: Cerradão, continuous maize, soil water potential.

\footnotetext{
(1) Parte da Tese de Doutorado do Primeiro autor. Recebido para publicação em março de 2008 e aprovado em janeiro de 2010.

(2) Doutora em Solos e Nutrição de Plantas, Universidade Federal de Viçosa - UFV. Av. Peter Henry Rolfs s/n, CEP 36570-000 Viçosa (MG). E-mail: ermelindamota@yahoo.com.br.

(3) Professor do Departamento de Solos, UFV. Bolsista CNPq. E-mails: hruiz@ufv.br; vhav@ufv.br

(4) Professor do Departamento de Engenharia Agrícola, UFV. Bolsista CNPq. E-mail: pafonso@ufv.br

(5) Mestrando do Programa de Pós-graduação em Solos e Nutrição de Plantas, UFV. E-mails: fehq@ig.com.br; ivancarreiro@yahoo.com.br
} 


\title{
RESUMO: IMPORTÂNCIA DO FLUXO DE MASSA E DA DIFUSÃO NO SUPRIMENTO DE NUTRIENTES AO MILHO E DA COMPOSIÇÃO DO EXSUDATO XILÉMATICO EM RESPOSTA AO TAMANHO DOS AGREGADOS E AO POTENCIAL DA ÁGUA DO SOLO
}

\begin{abstract}
O transporte de nutrientes até as raizes é essencialmente efetuado por fluxo de massa e difusão. O objetivo deste trabalho foi quantificar a contribuição desses dois mecanismos na aquisição de macronutrientes ( $N, P, K, C a, M g$ e $S$ ) e de micronutrientes catiônicos (Fe, Mn, Zn $e \mathrm{Cu}$ ) por plantas de milho, e o volume e a composição do exsudato xilemático em resposta ao tamanho dos agregados e à disponibilidade de água. O experimento foi conduzido em casa de vegetação com amostras de um Latossolo Vermelho, retiradas sob dois sistemas de manejo: cerradão sem manejo (CER) e cultivo contínuo com milho em manejo convencional por mais de 30 anos $(C C M)$. Os tratamentos corresponderam ao arranjo fatorial $[2 x(1+2) x 2]$, sendo dois sistemas de manejo (CER e CCM), $(1+2)$ solo passado em peneira de $4 \mathrm{~mm}$ e duas classes de agregados (<0,5 mm e entre 0,5 e 4,0 mm), e dois potenciais de água do solo (-40 e-10 kPa). Eles foram dispostos em delineamento em blocos casualizados, com quatro repetições. Aos 70 dias após a semeadura, finalizou-se o ensaio. A influência do tamanho do agregado e do potencial de água do solo nos mecanismos de transporte de nutrientes é maior nas amostras de solo com maiores concentrações de nutrientes em solução, sistema CER, tendo a difusão crescido em importância na condição de maior disponibilidade de água e nos agregados $<0,5 \mathrm{~mm}$. $O$ volume de exsudato xilemático colhido de plantas de milho aumenta com a diminuição do tamanho do agregado e com o aumento da disponibilidade de água do solo, no sistema CER. As maiores concentrações de Ca e Mg no exsudato xilemático das plantas cultivadas em amostras retiradas do sistema CER, dependeram das altas concentrações desses nutrientes na solução do solo neste sistema de manejo.
\end{abstract}

Termos de indexação: cerradão, cultivo contínuo com milho, conteúdo de água do solo.

\section{INTRODUCTION}

To be taken up by plants, the nutrients in the soil solution must be transported to the root surface. The mechanisms of solute transport to the roots are, essentially, mass flow and diffusion.

The mass flow is associated with the total potential gradient regulating the water movement in the soilplant-atmosphere. Thus, the soil solution concentration and plant transpiration rate determine the quantity of ions transported through this mechanism (Barber, 1974).

The relative importance of mass flow for nutrient supply depends on the supply capacity of the soil, besides the plant demand, characterized by differences in transpiration rate and nutrient uptake, which varies according to the plant species, root activity, soil water content and nutrient (Marschner, 1995). Mathematically, the quantity transported by mass flow $\left(\mathrm{FM}, \mathrm{kg} \mathrm{m}^{-2} \mathrm{~s}^{-1}\right)$ is given by:

$$
\mathrm{FM}=\mathrm{q} \mathrm{C}
$$

where $\mathrm{q}$ is the water flow $\left(\mathrm{m}^{3} \mathrm{~m}^{-2} \mathrm{~s}^{-1}\right)$ and $\mathrm{C}$ is the average solute concentration $\left(\mathrm{kg} \mathrm{m}^{-3}\right)$.

Nutrient diffusion, in turn, occurs through random thermal motion of ions towards the root, due to the concentration gradient near the root surface by the absorption process (Barber, 1984). The soil water content, the interaction of nutrient with soil colloids and the distance the nutrients must overcome to reach the root surface are the main factors governing this transport mechanism (Wild, 1981). The diffusion coefficient $\left(D_{\mathrm{S}}, \mathrm{m}^{2} \mathrm{~s}^{-1}\right)$ is calculated by the equation:

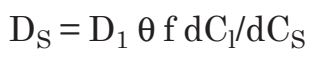

where $D_{1}$ is the diffusion coefficient in a pure solution $\left(\mathrm{m}^{2} \mathrm{~s}^{-1}\right), \theta$ is the soil water content, based on volume $\left(\mathrm{m}^{3} \mathrm{~m}^{-3}\right) ; \mathrm{f}$ is the impedance factor $\left(\mathrm{m} \mathrm{m}^{-1}\right)$, which includes, among other variables, the tortuosity of porous media, and $\mathrm{dC}_{\mathrm{l}} / \mathrm{dC}_{\mathrm{S}}$ is the inverse value of the buffering capacity, where $\mathrm{C}_{1}$ is the nutrient concentration in the soil solution, the intensity factor $\left(\mathrm{kg} \mathrm{L}^{-1}\right)$, and Cs the adsorbed nutrient, the quantity factor $\left(\mathrm{kg} \mathrm{m}^{-3}\right)$ (Novais \& Smyth, 1999).

Some authors also cite root interception as one of the mechanisms responsible for plant nutrient supply. This mechanism occurs when nutrients are intercepted by the roots during the growth process. Marschner (1995) reported that a small percentage of the total nutrient requirement is met by this process. Other authors believe that root interception should be disregarded because there is no possibility of a direct exchange between soil particles and plant roots without a liquid environment (Ruiz et al., 1999). 
After root uptake, the nutrients are translocated within the plant, reaching stems and leaves (Marschner, 1995). This transport occurs through the xylem and subsequently, nutrients are redistributed in the phloem. Nutrients are quickly distributed through the corrente transpiracional/ transpiration current (Larcher, 2000). It is therefore important to know the composition of the xylem exudate to evaluate nutrient absorption and translocation from roots to the aerial part. The study of the xylem sap is, in essence, one of the most representative of the actual conditions of plant nutrition (Vale et al., 1984).

The predominant mechanism for the transport of a nutrient is determined by its concentration in the solution moving toward the roots in response to the potential difference. When the nutrient amount that reaches the roots is equal to or exceeds the absorbed quantity, mass flow is the only relevant mechanism. In this case, the excess nutrients would accumulate in the rhizosphere (Barber, 1974). When the nutritional requirement of the plant exceeds the amount carried by mass flow, diffusion becomes the complementary mechanism, which may even exceed in importance the mass flow (Barber, 1962; Araújo et al., 2003).

Decreased water availability in the soil reduces the nutrient movement by mass flow and diffusion. These conditions lead to stomatal closure and consequent reduction of both flow transpiration as well as mass flow. In addition, it also decreases the amount of $\mathrm{CO}_{2}$ entering the stomata, and the root water and nutrient uptake. Under these conditions, plant growth is reduced and the amount of plantavailable water becomes a limiting factor for growth (Costa et al., 1997; Barros \& Comerford, 2002).

The contribution of mass flow and diffusion to transport nutrients to the roots can be calculated roughly by measuring the individual contributions and comparing them with the total plant nutrient uptake. In practice, the total nutrient accumulation and the contribution of mass flow are generally determined; the difference between the total amount absorbed and the quantity transported by mass flow was attributed to diffusion (Barber, 1984). This technique allows estimating the average contributions during the test period.

In soils, the nutrient movement to the roots includes two steps. At first, the transport from the aggregate interior to the surface occurs by diffusion in motionless solution (intra-aggregate porosity). In the second, from the aggregate surface to the roots, transport in the mobile solution is necessarily carried out by mass flow. However, in weathered soils such as Oxisols with a low nutrient concentration in the soil solution, the mass flow is mostly insufficient to meet the plant demand for some nutrients. Thus, diffusion becomes a complementary mechanism, or even the predominant mechanism in the nutrient supply to the plant roots, as observed by Ruiz et al. (1999) and Araújo et al. (2003).

This study aimed to quantify the contribution of mass flow and diffusion to the acquisition of macronutrients (N, P, K, Ca, Mg and $\mathrm{S}$ ) and cationic micronutrients ( $\mathrm{Fe}, \mathrm{Mn}, \mathrm{Zn}$, and $\mathrm{Cu}$ ) by maize, and the volume and composition of xylem exudate in response to soil aggregate size and water potential in samples of an Oxisol, sampled in two management systems: savanna-like with no management (CER) and continuous maize under conventional management for more than 30 years (CCM).

\section{MATERIAL AND METHODS}

The experiment was conducted in a greenhouse using samples of an Oxisol collected at Embrapa Maize and Sorghum in Sete Lagoas, Minas Gerais, Brazil. The samples were collected in the surface layer (2-15 $\mathrm{cm}$ ) in two adjacent areas under different managements, one with natural Cerradão vegetation (CER), and the other with continuous maize under conventional system for more than 30 years (CCM).

These samples were air-dried and sieved through a $4 \mathrm{~mm}$ sieve. A part was used to separate dry aggregates into two diameter classes: $<0.5 \mathrm{~mm}$ and $0.5-4.0 \mathrm{~mm}$, in a sieve shaker (Produtest) with 50 x 50 $\mathrm{cm}$ sieves. No fertilizer was added to the soil samples. Both soil and aggregates were physically and chemically characterized (Table 1).

The test was conducted in a factorial $[2 \mathrm{x}$ $(1+2) \times 2]$ design with two management systems: savanna-like with no management (CER) and continuous maize under conventional management (CCM); $(1+2)$ soil sieved through $4 \mathrm{~mm}$ mesh and two aggregate classes $(<0.5$ and $0.5-4.0 \mathrm{~mm})$; and two soil water potentials ( -40 and $-10 \mathrm{kPa}$ ), arranged in randomized blocks with four replications. The experimental units consisted of plastic pots with 5 $\mathrm{dm}^{3}$ of soil or aggregates, with a previously adjusted moisture content of $-10 \mathrm{kPa}$.

After the period required for uniform moisture, maize was sown (variety BRS-3060) with six seeds per pot and thinned to three plants per pot seven days after germination. From sowing to thinning, the soil water potential in pots was adjusted to $-10 \mathrm{kPa}$. In the treatments of $-40 \mathrm{kPa}$ no water was added until the desired potential was reached. The soil water potential was controlled daily during the maize cultivation period, using one tensiometer per pot. Based on the data of the water amount applied, evapotranspiration was calculated. In addition to the potted plants two pots with no plants for each treatment were prepared, to monitor water loss by evaporation. Plant transpiration in each experimental unit was calculated as the difference between the water volume of evapotranspiration and of evaporation. 
Table 1. Physical and chemical characterization of soil and aggregates $(<0.5$ and $0.5-4.0 \mathrm{~mm})$ in samples of an Red Oxisol under two management systems ${ }^{(1)}$

\begin{tabular}{|c|c|c|c|c|c|c|}
\hline \multirow{2}{*}{ Characteristic } & \multicolumn{3}{|c|}{ CER } & \multicolumn{3}{|c|}{$\mathrm{CCM}$} \\
\hline & Soil & $<0.5$ & $0.5-4.0$ & Soil & $<0.5$ & $0.5-4.0$ \\
\hline Coarse sand $\left(\mathrm{kg} \mathrm{kg}^{-1}\right)^{(2)}$ & 0.110 & 0.070 & 0.140 & 0.130 & 0.060 & 0.240 \\
\hline Fine sand $\left(\mathrm{kg} \mathrm{kg}^{-1}\right)^{(2)}$ & 0.040 & 0.050 & 0.020 & 0.030 & 0.050 & 0.020 \\
\hline Silt $\left(\mathrm{kg} \mathrm{kg}^{-1}\right)^{(2)}$ & 0.110 & 0.110 & 0.100 & 0.110 & 0.110 & 0.070 \\
\hline Clay $\left(\mathrm{kg} \mathrm{kg}^{-1}\right)^{(2)}$ & 0.740 & 0.770 & 0.740 & 0.730 & 0.780 & 0.670 \\
\hline Aggregate size distribution $\left(\mathrm{kg} \mathrm{kg}^{-1}\right)^{(3)}$ & - & 0.418 & 0.582 & - & 0.600 & 0.400 \\
\hline \multicolumn{7}{|l|}{ Soil water content $\left(\mathrm{kg} \mathrm{kg}^{-1}\right)$} \\
\hline$-10 \mathrm{kPa}$ & 0.359 & 0.420 & 0.327 & 0.392 & 0.400 & 0.291 \\
\hline$-40 \mathrm{kPa}$ & 0.322 & 0.347 & 0.316 & 0.312 & 0.339 & 0.272 \\
\hline $\mathrm{N}-\mathrm{NO}_{3}^{-}\left(\mathrm{mg} \mathrm{dm}^{-3}\right)^{(4)}$ & 19.77 & 24.78 & 20.79 & 7.81 & 10.31 & 7.73 \\
\hline $\mathrm{N}-\mathrm{NH}_{4}^{+}\left(\mathrm{mg} \mathrm{dm}^{-3}\right)^{(5)}$ & 8.07 & 8.67 & 7.90 & 3.64 & 3.56 & 3.15 \\
\hline $\mathrm{P}\left(\mathrm{mg} \mathrm{dm}^{-3}\right)^{(6)}$ & 5.00 & 7.00 & 4.70 & 9.40 & 9.90 & 8.70 \\
\hline $\mathrm{K}\left(\mathrm{mg} \mathrm{dm} \mathrm{m}^{-3}\right)^{(6)}$ & 67.00 & 64.00 & 54.00 & 91.00 & 86.00 & 73.00 \\
\hline $\mathrm{Ca}^{2+}\left(\mathrm{cmol}_{\mathrm{c}} \mathrm{dm}^{-3}\right)^{(7)}$ & 3.74 & 3.72 & 3.13 & 1.43 & 1.45 & 1.14 \\
\hline $\mathrm{Mg}^{2+}\left(\mathrm{cmol}_{\mathrm{c}} \mathrm{dm}^{-3}\right)^{(7)}$ & 0.76 & 0.74 & 0.64 & 0.34 & 0.34 & 0.28 \\
\hline $\mathrm{S}\left(\mathrm{mg} \mathrm{dm} \mathrm{m}^{-3}\right)^{(8)}$ & 1.60 & 1.20 & 1.40 & 2.70 & 2.70 & 2.70 \\
\hline $\mathrm{Fe}\left(\mathrm{mg} \mathrm{dm}^{-3}\right)^{(6)}$ & 33.70 & 43.10 & 32.40 & 28.20 & 26.80 & 42.90 \\
\hline $\operatorname{Mn}\left(\mathrm{mg} \mathrm{dm}^{-3}\right)^{(6)}$ & 58.80 & 98.00 & 50.30 & 39.50 & 42.50 & 53.70 \\
\hline $\mathrm{Zn}\left(\mathrm{mg} \mathrm{dm}^{-3}\right)^{(6)}$ & 1.52 & 2.21 & 1.05 & 4.11 & 3.99 & 4.88 \\
\hline $\mathrm{Cu}\left(\mathrm{mg} \mathrm{dm}^{-3}\right)^{(6)}$ & 0.49 & 0.58 & 0.42 & 0.61 & 0.67 & 0.74 \\
\hline pH (soil:water 1: 2,5) & 5.18 & 5.22 & 5.21 & 5.34 & 5.07 & 5.18 \\
\hline $\mathrm{Al}^{3+}\left(\mathrm{cmol}_{\mathrm{c}} \mathrm{dm}^{-3}\right)^{(7)}$ & 0.10 & 0.10 & 0.10 & 0.34 & 0.34 & 0.24 \\
\hline $\mathrm{H}+\mathrm{Al}\left(\mathrm{cmol}_{\mathrm{c}} \mathrm{dm}^{-3}\right)^{(8)}$ & 10.20 & 10.20 & 8.70 & 9.70 & 10.00 & 8.10 \\
\hline Organic carbon $\left(\mathrm{g} \mathrm{kg}^{-1}\right)^{(9)}$ & 49.9 & 51.8 & 47.2 & 40.0 & 40.0 & 38.6 \\
\hline
\end{tabular}

(1) Natural Cerradão vegetation without management (CER) and continuous maize under conventional management (CCM). ${ }^{(2)}$ Ruiz (2005). (3) Dry sieving (Embrapa, 1997). ${ }^{(4)}$ Yang et al. (1998). ${ }^{(5)}$ Kempers \& Zweers (1986). (6) Mehlich-1 extraction solution (Defelipo \& Ribeiro, 1981). (7) Extraction solution $\mathrm{KCl} 1 \mathrm{~mol} \mathrm{~L}^{-1}$ (Embrapa, 1997). (8) Extraction solution calcium acetate 0.5 mol L ${ }^{-1}$ pH 7.0 (Embrapa, 1997). ${ }^{(9)}$ Yeomans \& Bremner (1988).

Plants were harvested 70 days after emerging and divided in aerial parts and roots. After cutting the aerial part the xylem exudate was collected by direct contact with capillary tubs in the incision region for $2 \mathrm{~h}$. The exudate was always collected in the early morning, sampling two blocks per day.

The xylem exudate was placed in glass vials previously weighed with an accuracy of $\pm 0.0001 \mathrm{~g}$, determining the whole mass of the set. The collected volume was estimated by weight difference, assuming a value of $10,000 \mathrm{~kg} \mathrm{~L}^{-1}$ for solution density. In this material, the concentration of $\mathrm{P}, \mathrm{K}, \mathrm{Ca}, \mathrm{Mg}, \mathrm{S}, \mathrm{Fe}$, $\mathrm{Mn}, \mathrm{Zn}$, and $\mathrm{Cu}$ was determined by direct reading in an Inductively Coupled Plasma Optical Emission Spectrometer (ICP-OES). Using the concentrations of these nutrients and the amount of exudate collected in each experimental unit, the content of $\mathrm{P}, \mathrm{K}, \mathrm{Ca}$, $\mathrm{Mg}, \mathrm{S}, \mathrm{Fe}, \mathrm{Mn}, \mathrm{Zn}$, and $\mathrm{Cu}$ in the xylem exudate was calculated.

Soil and aggregate samples of all treatments were dried and sieved to $2 \mathrm{~mm}$. Then, three sub-samples were taken for soil solution extraction. To each $1 \mathrm{dm}^{3}$ sub-sample of either soil or aggregate the water volume required to achieve a moisture content of $-5 \mathrm{kPa}$ was added. After a period of $8 \mathrm{~h}$ of equilibrium, the soil solution of each of these sub-samples was extracted with pressure membrane extractor at $1000 \mathrm{kPa}$ for $12 \mathrm{~h}$. The concentration of K, $\mathrm{Ca}, \mathrm{Mg}, \mathrm{S}, \mathrm{Fe}, \mathrm{Mn}, \mathrm{Zn}$, and $\mathrm{Cu}$ was determined, by direct reading in ICPOES in each extracted solution. $\mathrm{P}, \mathrm{N}^{-\mathrm{NO}_{3}}{ }_{3}$ and $\mathrm{N}$ $\mathrm{NH}_{4}{ }^{+}$were determined by colorimetry (Braga \& Defelipo, 1974; Kempers \& Zweers, 1986; Yang et al., 1998).

The amounts of $\mathrm{N}, \mathrm{P}, \mathrm{K}, \mathrm{Ca}, \mathrm{Mg}, \mathrm{S}, \mathrm{Fe}, \mathrm{Mn}, \mathrm{Zn}$, and $\mathrm{Cu}$ transported by mass flow were determined by multiplying the concentration of each nutrient in the soil solution by the water volume transpired in the test period. The diffusion was calculated by subtracting the amount transported by mass flow from the total nutrient uptake (aerial part + roots) (Ruiz et al., 1999; Rosolem et al., 2003; Oliveira et al., 2004). With the values of mass flow and diffusion, the relative contribution of each mechanism to nutrient transport was calculated. 
The results were submitted to analysis of variance. The effect of management system was compared and five orthogonal contrasts were used in each soil management system, CER and CCM (Table 2). Two

Table 2. Contrasts (C) used in the comparison of soil or aggregates (AG), and soil water potential ( $\Psi)$, in each management system ${ }^{(1)}$

\begin{tabular}{lrrrrrr}
\hline \multicolumn{1}{c}{ Material } & $\boldsymbol{\Psi}$ & $\mathbf{C}_{1}$ & $\mathbf{C}_{2}$ & $\mathbf{C}_{3}$ & $\mathbf{C}_{4}$ & $\mathbf{C}_{5}$ \\
\hline \multirow{4}{*}{ Soil } & $\mathrm{kPa}$ & & & & & \\
\multirow{4}{*}{ AG $<0,5 \mathrm{~mm}$} & -40 & -2 & 0 & -1 & 0 & 0 \\
\multirow{4}{*}{ AG 0,5-4,0 mm } & -10 & -2 & 0 & 1 & 0 & 0 \\
& -10 & 1 & -1 & 0 & -1 & 0 \\
& -40 & 1 & -1 & 0 & 1 & 0 \\
& -10 & 1 & 1 & 0 & 0 & -1 \\
\end{tabular}

(1) $\mathrm{C}_{1}$ : soil vs. AG. $\mathrm{C}_{2}$ : $\mathrm{AG}<0.5 \mathrm{~mm}$ vs. $\mathrm{AG} 0.5-4.0 \mathrm{~mm} . \mathrm{C}_{3}$ : $\Psi-40 \mathrm{kPa} v s . \Psi-10 \mathrm{kPa}$ for the soil. $\mathrm{C}_{4}: \Psi-40 \mathrm{kPa}$ vs. $\Psi-10 \mathrm{kPa}$ for $\mathrm{AG}<0.5 \mathrm{~mm} . \mathrm{C}_{5}: \Psi-40 \mathrm{kPa}$ vs. $\Psi-10 \mathrm{kPa}$ for AG $0.5-4.0 \mathrm{~mm}$. additional contrasts $\left(\mathrm{CA}_{1}\right.$ and $\left.\mathrm{CA}_{2}\right)$ were included to decompose the effect of the potential within each aggregate class. Mean contrasts were used, dividing the result of each contrast by $1 / 20$ Ó $\left|c_{i}\right|$, where $\mid$ ci $\mid$ denotes the absolute value of its coefficient (Alvarez V. \& Alvarez, 2006). The significance of contrasts was tested statistically by the F-test at 5 and $1 \%$.

\section{RESULTS AND DISCUSSION}

When comparing the management systems natural Cerradão vegetation (CER) versus continuous maize under conventional management for over 30 years (CCM), it appears that the nutrient uptake in plants grown in soil or aggregate samples from the CER system was greater, except in the case of $\mathrm{K}$ (Figures 1 and 2). This response may be due to a higher nutrient concentration in the soil solution (Table 3) and also to the greater nutrient availability, with exception of P, K and S in the CER system (Table 1).

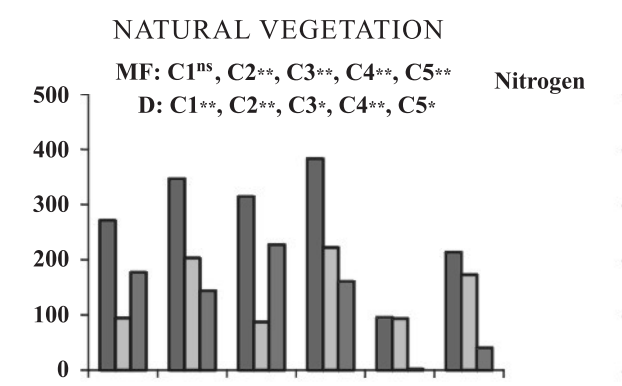

CONTINUOUS MAIZE CROPPING

$\mathrm{MF}: \mathrm{C1} 1^{*}, \mathrm{C2}^{* *}, \mathrm{C}^{\mathrm{ns}}, \mathrm{C} 4^{\mathrm{ns}}, \mathrm{C}^{* * *}$

$\mathrm{D}: \mathrm{C} 1 *, \mathrm{C} 2^{* * *}, \mathrm{C}^{\mathrm{ns}}, \mathrm{C}^{\mathrm{ns}}, \mathrm{C}^{\mathrm{ns}}$

Total nutrient accumulation

Mass flow

Diffusion

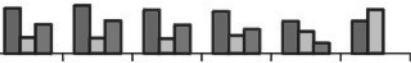
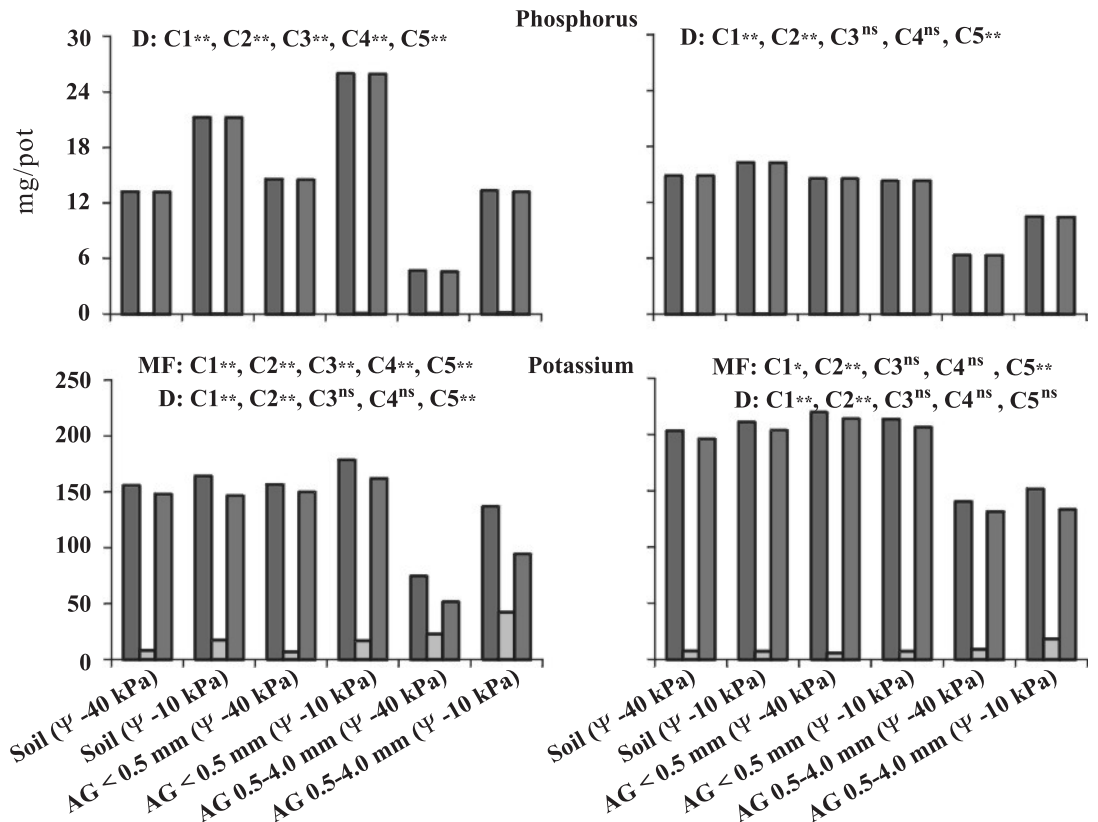

Figure 1. Total nitrogen, phosphorus and potassium accumulation in maize plants and quantities supplied by mass flow (MF) and diffusion (D), considering the material used for testing, soil or aggregates (AG), the water potential $(\Psi)$ and the management system. Natural vegetation or continuous maize cropping. $\mathrm{C}_{1}$ : soil vs. AG. $\mathrm{C}_{2}: \mathrm{AG}<0.5 \mathrm{~mm} v s$. AG 0.5-4.0 mm. $\mathrm{C}_{3}: \Psi-40 \mathrm{kPa} v s . \Psi-10 \mathrm{kPa}$ for soil. $\mathrm{C}_{4}: \Psi-40 \mathrm{kPa} v s . \Psi$ $-10 \mathrm{kPa}$ for $\mathrm{AG}<0.5 \mathrm{~mm} . \mathrm{C}_{5}: \Psi-40 \mathrm{kPa} v s . \Psi-10 \mathrm{kPa}$ for AG 0.5-4.0 mm. * and ** significant at 5 and $1 \%$, respectively, by the $\mathrm{F}$ test. 


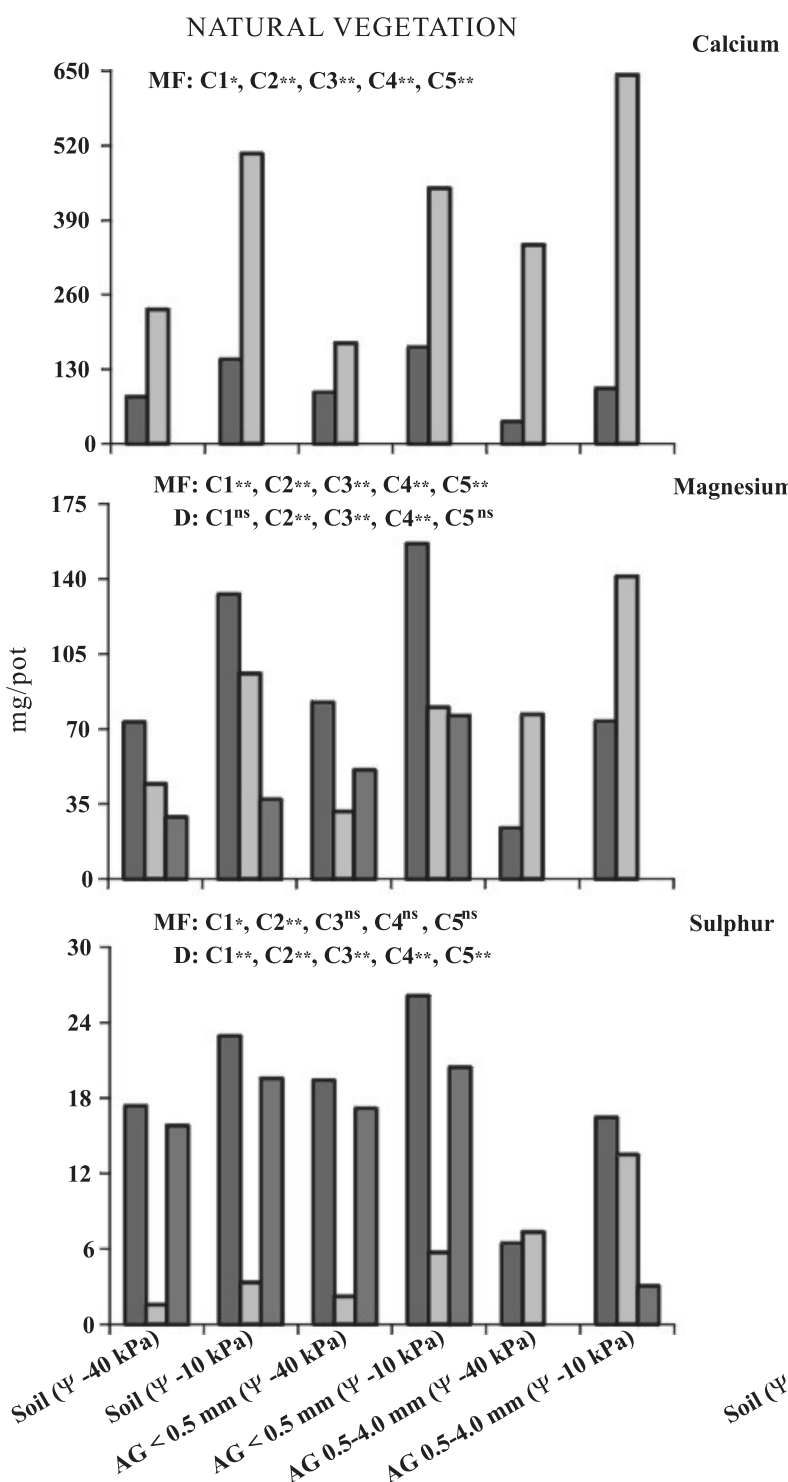

CONTINUOUS MAIZE CROPPING

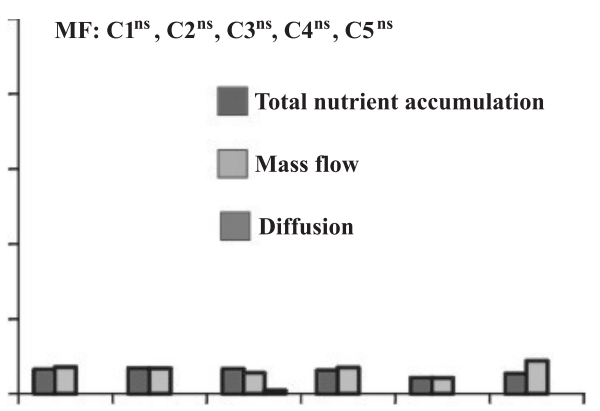

$\mathrm{MF}: \mathrm{C}^{\mathrm{ns}}, \mathrm{C}^{\mathrm{ns}}, \mathrm{C}^{\mathrm{ns}}, \mathrm{C}^{\mathrm{ns}}, \mathrm{C}^{\mathrm{ns}}$

D: $\mathrm{C1}^{\mathrm{ns}}, \mathrm{C2}{ }^{*}, \mathrm{C}^{\mathrm{ns}}, \mathrm{C}^{\mathrm{ns}}, \mathrm{C}^{\mathrm{ns}}$

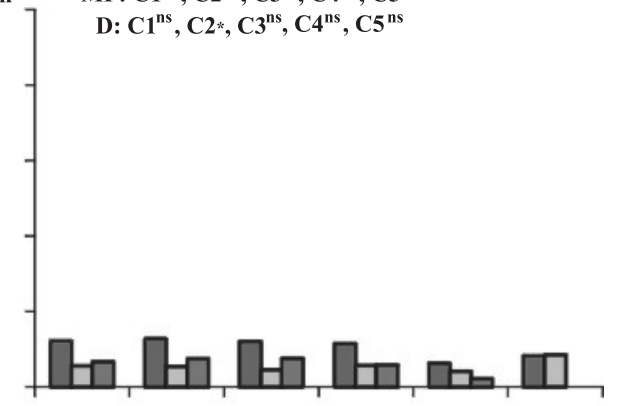

$\mathrm{MF}: \mathrm{C} 1^{*}, \mathrm{C} 2^{* *}, \mathrm{C}^{\mathrm{ns}}, \mathrm{C} 4^{\mathrm{ns}}, \mathrm{C} 5^{* *}$

D: $\mathrm{C} 1 * *, C 2 * *, \mathrm{C}^{\text {ns }}, \mathrm{C}^{\text {ns }}, \mathrm{C}^{\text {ns }}$

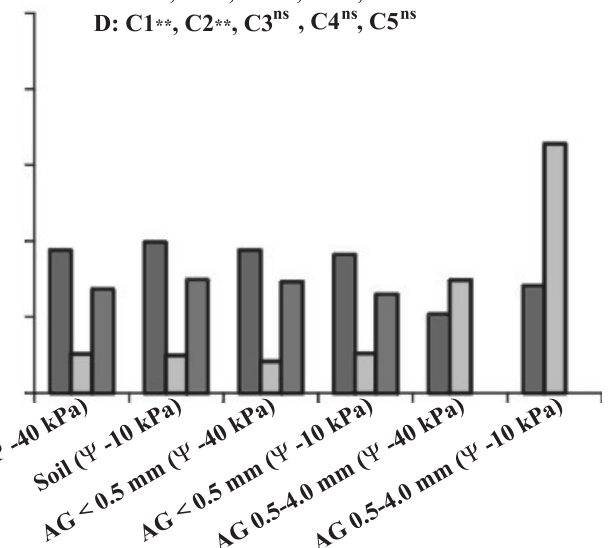

Figure 2. Total calcium, magnesium and sulphur accumulation in maize plants and quantities supplied by mass flow (MF) and diffusion (D), considering the material used for testing, soil or aggregates (AG), the water potential $(\Psi)$ and the management system. Natural vegetation or continuous maize cropping. $C_{1}$ : soil vs. AG. $\mathrm{C}_{2}$ : AG<0.5 mm vs. AG $0.5-4.0 \mathrm{~mm}$. $\mathrm{C}_{3}$ : $\Psi-40 \mathrm{kPa} v s . \Psi-10 \mathrm{kPa}$ for soil. $\mathrm{C}_{4}$ : $\Psi-40 \mathrm{kPa}$ vs. $\Psi$ $10 \mathrm{kPa}$ for $\mathrm{AG}<0.5 \mathrm{~mm} . \mathrm{C}_{5}: \Psi-40 \mathrm{kPa} v s . \Psi-10 \mathrm{kPa}$ for $\mathrm{AG}$ 0.5-4.0 mm. * and ** significant at 5 and $1 \%$, respectively, by the $\mathrm{F}$ test.

Chemical analysis (Table 1) showed that $\mathrm{N}$ is the decisive nutrient for the cited differences, which resulted in significantly higher values of nutrient uptake, especially of $\mathrm{N}, \mathrm{Ca}$ and $\mathrm{Mg}$ under CER, compared to CCM (Figures 1 and 2). It is noteworthy that dry matter production under CER was also higher in the aerial part $(14.47 \mathrm{mg} / \mathrm{pot})$ and roots $(5.43 \mathrm{mg} /$ pot) than in CCM ( $8.91 \mathrm{mg} /$ pot and $3.47 \mathrm{mg} /$ pot). This explains why the low $\mathrm{N}$ availability in the soil samples from the area under CCM limited the dry matter production of plants grown in this management system

In the case of the longstanding use of the conventional system with periodic fertilization over
30 years $(\mathrm{CCM})$, the results of soil chemical characterization showed that this period was sufficient to reduce the soil nutrient levels, except for $\mathrm{P}, \mathrm{K}$ and $\mathrm{S}$ (Table 1). The first two nutrients are generally incorporated in higher quantities, mainly in the case of $\mathrm{P}$, and $\mathrm{S}$ can be incorporated when ordinary superphosphate is used. This finding justifies the lower nutrient concentrations in the soil solution of plants grown on samples from CCM (Table 3).

The low nutrient concentration in the soil solution was due to nutrient depletion in the soil solution in the 70 days of the test (Table 3). It is noteworthy that these concentrations were used to estimate nutrient transport by mass flow. Assuming that the 
Table 3. Nutrient concentration in the soil solution, considering the material used for testing, soil or aggregates (AG), and the management system (MS) ${ }^{(1)}$

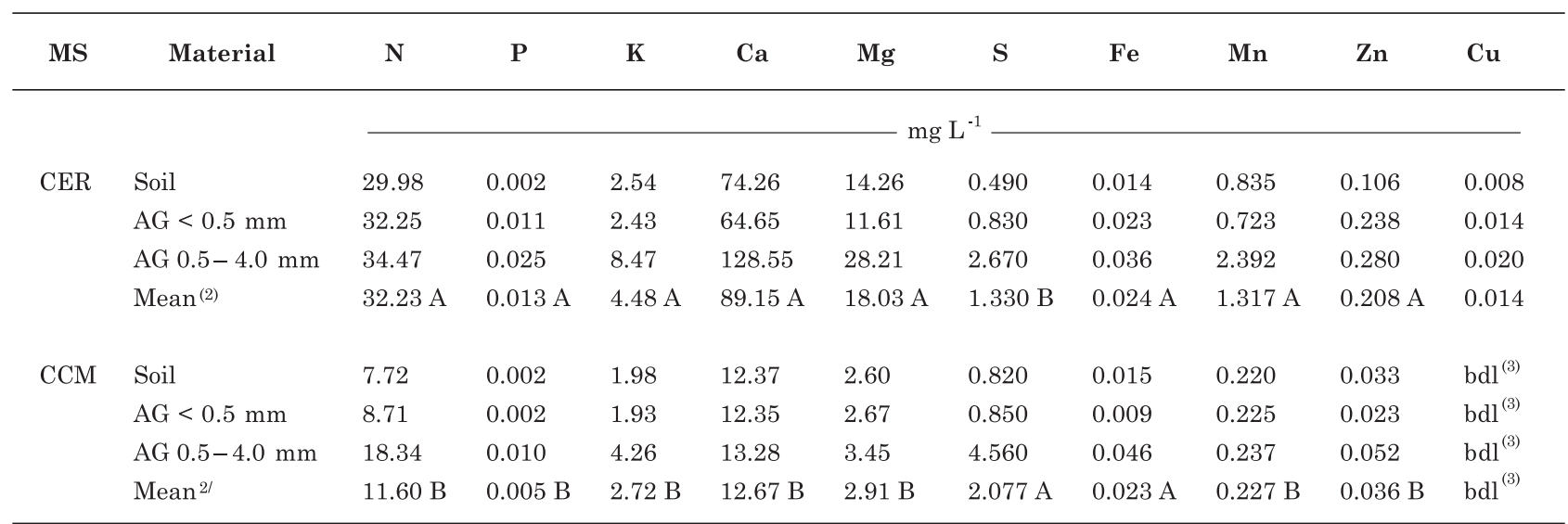

(1) Natural Cerradão vegetation (CER) and continuous maize under conventional management (CCM). ${ }^{(2)}$ Different letters in column indicate differences at $1 \%$ by the $\mathrm{F}$ test for management system. ${ }^{(3)}$ Concentration below the detection limit of ICP-OES.

nutrient concentration in the soil solution was constant from the beginning of the experiment may have been an underestimation of the contribution of mass flow and overestimation of diffusion, since the latter was determined by the difference between the total plant uptake and the amount supplied by mass flow. The contribution of root interception was disregarded since the percentage of contribution of this mechanism to the process of nutrient transport to plant roots is negligible.

Of the nutrient supply mechanisms to plants roots, mass flow was the main mechanism for $\mathrm{Ca}, \mathrm{Mg}$ and $\mathrm{N}$ (Figures 1 and 2), in agreement with results obtained for maize by Vargas et al. (1983) and for rice by Ruiz et al. (1999). In all treatments, the Ca amount transported by mass flow exceeded the amount accumulated in the plants, aside from those grown on smaller aggregates $(<0.5 \mathrm{~mm})$, with reduced water availability $(-40 \mathrm{kPa})$ in soil samples from the CCM system (Figure 2). This result confirms the existence of mechanisms responsible for a decreased uptake of this nutrient when the plant demand is met, e.g., $\mathrm{Ca}$ accumulation on the root surface.

There is a pronounced difference in $\mathrm{N}, \mathrm{Ca}$, and $\mathrm{Mg}$ uptake between samples from the CER and from the CCM system (Figures 1 and 2). This result can be explained by the higher concentration of these nutrients in soil solution samples from the CER system (Table 3), resulting in higher transport by mass flow (Figures 1 and 2).

The transport of sulfur to maize roots was not only related to mass flow, but also to diffusion, depending on the management system, CER or CCM (Figure 2). Thus, mass flow contributed with $40 \%$ of S supply to the roots in the CER and $51 \%$ in the CCM system. Obviously, the contribution of diffusion had an inverse effect. This difference is mainly due to higher concentrations of this nutrient in CCM soil solution samples, favoring the mass-flow transport (Table 3). At adequate concentrations in the soil, the supply of other nutrients that may be carried solely by mass flow may be complemented by the diffusion process, when the concentrations of these nutrients are low in soil solution. This was observed for nitrogen (Okajima \& Taniyama, 1980; Strebel \& Duynisveld, 1989) and magnesium (Al-Abbas \& Barber, 1964; Vargas et al., 1983).

For K, the predominant mechanism was diffusion, contributing with nearly 85 and $95 \%$ of $\mathrm{K}$ absorbed in the CER and CCM systems, respectively (Figure 1), which is consistent with results obtained by Barber (1974). This author cites diffusion as the main transport mechanism of potassium in the soil solution to plant roots, accounting for $86 \%$ of its supply, while mass flux and root interception represented 11 and $3 \%$, respectively. In Brazil, working with different soils of Rio Grande do Sul, Vargas (1983) found that the diffusion mechanism contributed with 72 - $95 \%$ of the potassium supply for maize. Ruiz (1999), Rosolem et al. (2003) and Fernandes (2006) also found that diffusion was the main supply mechanism of $\mathrm{K}$ to plant roots.

It was observed that diffusion was also the main transport mechanism for $\mathrm{P}, \mathrm{Fe}, \mathrm{Mn}, \mathrm{Zn}$, and $\mathrm{Cu}$, mainly for aggregates $<0.5 \mathrm{~mm}$ and highest water potential $(-10 \mathrm{kPa})$, regardless of the management system CER or CCM (Figure 1 and Table 4). This result is justified by the low concentration of these nutrients in the soil solution and the greater water availability in smaller aggregates (Tables 1 and 3). These results corroborate those of other authors (Vargas et al., 1983; Nunes et al., 2004).

$\mathrm{Cu}$ transported by mass flow and by diffusion in the CER and CCM samples was not included in Table 4 since the element was not detected by the analytical method used in the analyses of soil solution and of the 
aggregates separated from the CCM sample (Table 3). The low $\mathrm{Cu}$ concentration in the solution extracted from CER samples indicates that more than $99 \%$ of the transport of this nutrient must be attributed to diffusion. The lower $\mathrm{Cu}$ concentration in the CCM samples suggests that under these conditions, the contribution of diffusion would be proportionately greater.

The percentage contribution of transport by mass flow for both management systems was: $\mathrm{Ca}>\mathrm{Mg}>\mathrm{N}$ $>\mathrm{S}>\mathrm{K}>\mathrm{P} \approx \mathrm{Mn} \approx \mathrm{Zn} \approx \mathrm{Fe} \approx \mathrm{Cu}$. The mean for the first five is 100, 70, 60, 40 and $15 \%$, respectively (CER) and $98,57,52,51$ and $5 \%(\mathrm{CCM})$. Diffusion is the main transport mechanism of $\mathrm{K}, \mathrm{P}, \mathrm{Fe}, \mathrm{Mn}, \mathrm{Zn}$, and $\mathrm{Cu}$ to the surface of maize roots in both management systems, accounting for values above $99 \%$ except for $\mathrm{K}$, where the value is $85 \%$ for the CER system and $95 \%$ for the CCM system.

Comparing the aggregate size in both systems, CER and CCM $\left(\mathrm{C}_{2}\right.$ : aggregate size, $\mathrm{AG}<\mathrm{AG} 0.5 \mathrm{~mm}$ vs. 0.5 to $4.0 \mathrm{~mm})$, it appears that the contribution of mass flow to nutrient supply increases in larger aggregates (Figures 1 and 2), especially in the CER system: $\mathrm{Ca}$ $\left(\mathrm{C}_{2}: 187.5^{* *} \mathrm{mg} / \mathrm{pot}\right), \mathrm{Mg}\left(\mathrm{C}_{2}: 53.23^{* * *} \mathrm{mg} / \mathrm{pot}\right), \mathrm{S}\left(\mathrm{C}_{2}\right.$ : $\left.6.35^{* * *} \mathrm{mg} / \mathrm{pot}\right)$ and $\mathrm{K}\left(\mathrm{C}_{2}: 21.13^{* * *} \mathrm{mg} / \mathrm{pot}\right)$, and under CCM: N ( $\left.\mathrm{C}_{2}: 29.69^{* *} \mathrm{mg} / \mathrm{pot}\right), \mathrm{S}\left(\mathrm{C}_{2}: 11.78^{* *} \mathrm{mg} / \mathrm{pot}\right)$ $\mathrm{K}\left(\mathrm{C}_{2}: 7.21^{* *} \mathrm{mg} / \mathrm{pot}\right)$. In the case of diffusion, the behavior is obviously inversed. In this more sandy material (0.5-4.0 $\mathrm{mm}$ aggregates), the lower interaction of nutrients with the components of the soil solid phase favored higher concentrations in soil solution (Table 3). It is likely that this result is also due to the tortuosity of the porous environment. In larger, more sandy aggregates, tortuosity is higher under unsaturated conditions than in smaller aggregates. So when there is a reduction in the impedance factor of the material formed by larger aggregates, the nutrient supply by diffusion to the root surface is reduced. This explanation is valid, because under non-saturated conditions the hydraulic conductivity decreases more sharply in sandy than in clay soils (Hillel, 1971).

On the other hand, contribution of the transport mechanism by diffusion in aggregates $<0.5 \mathrm{~mm}$ was greater in both management systems, but more markedly in CER (Figures 1 and 2). The differences between the aggregate sizes may be related to increased water retention with decreasing aggregate size (Table 1), due to increased clay and organic matter content in those aggregates. The higher water content in smaller aggregates favors diffusion by its direct effect on the diffusion coefficient and by reducing the tortuosity of the diffusive path, thus increasing the impedance factor and, consequently, the coefficient of diffusion (Barber, 1984).

Another fact to consider is the high concentration of fine roots in the aggregates $<0.5 \mathrm{~mm}$, in the CER system. The higher values of root dry weight in the aggregates $<0.5 \mathrm{~mm}(12.44 \mathrm{~g} / \mathrm{pot})$ compared to aggregates $0.5-4.0 \mathrm{~mm}(8.48 \mathrm{~g} / \mathrm{pot})$ allow the conclusion that in aggregates $<0.5 \mathrm{~mm}$ the depletion zone around the roots that favored diffusion was larger

Table 4. Total Fe, Mn and Zn accumulation in maize plants and quantities supplied by mass flow (MF) and diffusion (D), considering the material used for testing, soil or aggregates (AG), the water potential (ø) and the management system (MS) $)^{(1)}$

\begin{tabular}{|c|c|c|c|c|c|c|c|c|c|c|c|}
\hline \multirow{2}{*}{ MS } & \multirow{2}{*}{ Material } & \multirow{2}{*}{$\Psi$} & \multicolumn{3}{|c|}{$\mathbf{F e}$} & \multicolumn{3}{|c|}{ Mn } & \multicolumn{3}{|c|}{$\mathrm{Zn}$} \\
\hline & & & Total & MF & D & Total & MF & D & Total & MF & D \\
\hline & & $\mathrm{kPa}$ & & & & 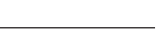 & $\mathrm{mg} / \mathrm{pot}$ & 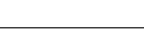 & & & - \\
\hline \multirow[t]{7}{*}{ CER } & Soil & -40 & $10,114.36$ & 0.04 & $10,114.31$ & $2,102.00$ & 2.63 & 2099.37 & 763.01 & 0.33 & 762.68 \\
\hline & & -10 & $16,955.30$ & 0.10 & $16,955.21$ & $2,974.85$ & 5.69 & $2,969.16$ & 953.04 & 0.72 & 952.32 \\
\hline & $\mathrm{AG}<0.5 \mathrm{~mm}$ & -40 & $12,149.79$ & 0.06 & $12,149.73$ & $2,359.01$ & 1.95 & $2,357.06$ & 837.77 & 0.64 & 837.12 \\
\hline & & -10 & $17,986.66$ & 0.16 & $17,986.50$ & $4,001.23$ & 4.98 & $3,996.25$ & $1,126.54$ & 1.64 & $1,124.90$ \\
\hline & AG $0.5-4.0 \mathrm{~mm}$ & -40 & $3,245.89$ & 0.10 & $3,245.79$ & 967.24 & 6.51 & 960.73 & 246.00 & 0.76 & 245.23 \\
\hline & & -10 & $12,308.75$ & 0.18 & $12,308.57$ & $2,079.92$ & 12.01 & $2,067.91$ & 738.54 & 1.41 & 737.13 \\
\hline & $\operatorname{Mean}^{(2)}$ & & $12,126.79 \mathrm{~A}$ & $0.11 \mathrm{~A}$ & $12,126.69 \mathrm{~A}$ & $2,414.04 \mathrm{~A}$ & $5.63 \mathrm{~A}$ & $2,408.41 \mathrm{~A}$ & $777.48 \mathrm{~A}$ & $0.92 \mathrm{~A}$ & $776.56 \mathrm{~A}$ \\
\hline \multirow[t]{7}{*}{$\mathrm{CCM}$} & Soil & -40 & $8,135.13$ & 0.06 & $8,135.07$ & $1,599.91$ & 0.82 & $1,599.09$ & 398.57 & 0.12 & 398.44 \\
\hline & & -10 & $9,550.53$ & 0.05 & $9,550.47$ & $1,388.41$ & 0.79 & $1,387.61$ & 405.74 & 0.12 & 405.62 \\
\hline & $\mathrm{AG}<0.5 \mathrm{~mm}$ & -40 & $9,892.57$ & 0.03 & $9,892.54$ & $1,554.75$ & 0.67 & $1,554.07$ & 535.98 & 0.07 & 535.91 \\
\hline & & -10 & $6,108.05$ & 0.03 & $6,108.02$ & $1,212.47$ & 0.83 & $1,211.63$ & 360.01 & 0.09 & 359.92 \\
\hline & $\mathrm{AG} 0.5-4.0 \mathrm{~mm}$ & -40 & $4,252.27$ & 0.10 & $4,252.17$ & $1,138.39$ & 0.50 & $1,137.89$ & 312.40 & 0.11 & 312.29 \\
\hline & & -10 & $5,012.49$ & 0.20 & $5,012.29$ & $1,188.42$ & 1.02 & $1,187.40$ & 325.40 & 0.22 & 325.18 \\
\hline & $\operatorname{Mean}^{(2)}$ & & $7,158.51 \mathrm{~B}$ & $0.08 \mathrm{~B}$ & $7,158.43 \mathrm{~B}$ & $1,347.06 \mathrm{~B}$ & $0.77 \mathrm{~B}$ & $1,346.28 \mathrm{~B}$ & $389.68 \mathrm{~B}$ & $0.12 \mathrm{~B}$ & $389.56 \mathrm{~B}$ \\
\hline
\end{tabular}

${ }^{(1)}$ Natural Cerradão vegetation (CER) and continuous maize under conventional management (CCM). ${ }^{(2)}$ Different letters in column indicate differences at $1 \%$ by the $\mathrm{F}$ test for management system. 
(Figures 1 and 2). This also demonstrates that eventual problems of aeration or compaction due to the predominance of small and more clayey aggregates were not sufficient to reduce the transport by diffusion in these materials.

When comparing the soil water potential, - 40 vs. $-10 \mathrm{kPa}\left(\mathrm{C}_{3}, \mathrm{C}_{4}\right.$ and $\left.\mathrm{C}_{5}\right)$, the increase in water availability led to a greater nutrient uptake, favoring mass flow and diffusion in the CER (Figure 1 and 2). In CCM samples, the effect of water potential on the nutrient transport was almost negligible, due to the low $\mathrm{N}$ availability in the system.

A positive and significant effect was observed in the contrasts comparing the soil water potentials -40 with. $-10 \mathrm{kPa}$ in $\mathrm{CER}\left(\mathrm{C}_{3}, \mathrm{C}_{4}\right.$ and $\left.\mathrm{C}_{5}\right)$ (Figures 1 and 2) and that the amount of nutrient transported by diffusion increased under greater water availability, especially $\mathrm{P}\left(\mathrm{C}_{3}: 8.04^{* *} ; \mathrm{C}_{4}: 11.39^{* *} ; \mathrm{C}_{5}: 8.62^{* *}\right), \mathrm{S}$ $\left(\mathrm{C}_{3}: 3.75^{* *} ; \mathrm{C}_{4}: 3.22^{* *} ; \mathrm{C}_{5}: 3.04^{* *}\right), \mathrm{Mg}\left(\mathrm{C}_{3}: 8.18^{* *} ; \mathrm{C}_{4}\right.$ : $\left.25.42^{* * *}\right)$ and $\mathrm{K}\left(\mathrm{C}_{5}: 42.81^{* *}\right)$ (Figures 1 and 2). This result was also observed for $\mathrm{Fe}, \mathrm{Mn}, \mathrm{Zn}$, and $\mathrm{Cu}$ (Table 3, contrasts not shown). The higher water content in soil encourages diffusion by its direct effect on the diffusion coefficient and by reducing the tortuosity of diffusion pathway, increasing the thickness of the water film within the pores. The moisture can also influence the ion distribution between the soil solid and liquid phases. Nye \& Tinker (1977) related the impedance factor (f) to soil moisture and found that in very dry soil, f showed very low values $\left(2 \times 10^{-4}\right.$ at a matric potential of $-10 \mathrm{MPa}$ and
$10^{-2}$ at $-1.5 \mathrm{MPa}$ ). When the potentials were between -0.1 and $-1.0 \mathrm{MPa}$, the impedance factor increased linearly similar to the water content. According to the authors, the impedance factor approaches zero in the driest soils reaching values between 0.4 and 0.7 in saturated soil.

The management systems CER and CCM influenced the exudate volume collected from maize plants (Table 5). It was observed that the volume collected within $2 \mathrm{~h}$ from plants grown on CER samples was approximately eight times higher than that collected from plants grown on soil under continuous cropping with conventional tillage maize (CCM). This result is consistent with the values of dry matter, which were higher in CER (19.9 g/pot) than in CCM (12.7 g/pot). This confirms that conditions for transport by mass flow and diffusion were more favorable in CER soil samples, which resulted in higher dry matter production.

Nutrient concentrations in the maize exudates were influenced by the management systems; significant differences were observed for all nutrients, except $\mathrm{S}$ (Table 5). It was not possible to determine $\mathrm{N}$, since $\mathrm{N}$ cannot be quantified by ICP-EOS and the exudate volume was insufficient for the specific analytical determination. Plants grown in CER soil samples had higher concentrations of $\mathrm{Ca}, \mathrm{Mg}$ and $\mathrm{Mn}$ and lower levels of $\mathrm{P}, \mathrm{K}, \mathrm{Fe}, \mathrm{Zn}$, and $\mathrm{Cu}$ (Table 5). Considering the five macronutrients determined in the exudate, the concentration ratio of the soil solutions when comparing the two management systems, CER and

Table 5. Volume (V) and mineral composition of the xylem exudate, considering the material used for testing, soil or aggregates $(\mathrm{AG})$, the water potential $(\Psi)$ and the management system $(\mathrm{MS})^{(1)}$

\begin{tabular}{|c|c|c|c|c|c|c|c|c|c|c|c|c|}
\hline MS & Material & $\Psi$ & $\mathrm{V}$ & $\mathbf{P}$ & K & $\mathbf{C a}$ & Mg & S & $\mathrm{Fe}$ & Mn & Zn & $\mathrm{Cu}$ \\
\hline & & $\mathrm{kPa}$ & $\mathrm{mL}$ & & & & & $\mathrm{mg} \mathrm{L}^{-1}$ & & & & \\
\hline \multirow{7}{*}{ CER } & Soil & -40 & 0.763 & 4.57 & 114.59 & 69.71 & 93.99 & 8.04 & 0.28 & 1.66 & 0.89 & 0.45 \\
\hline & & -10 & 2.228 & 7.35 & 60.39 & 51.21 & 63.54 & 4.45 & 0.20 & 1.21 & 0.57 & 0.19 \\
\hline & $\mathrm{AG}<0.5 \mathrm{~mm}$ & -40 & 1.025 & 3.98 & 171.03 & 71.21 & 95.87 & 8.24 & 0.20 & 2.17 & 0.96 & 0.36 \\
\hline & & -10 & 2.238 & 10.03 & 65.48 & 52.73 & 71.61 & 4.32 & 0.15 & 1.56 & 0.67 & 0.13 \\
\hline & AG $0.5-4.0 \mathrm{~mm}$ & -40 & 0.162 & 5.74 & 270.03 & 78.83 & 90.01 & 13.26 & 0.44 & 1.90 & 1.40 & 0.82 \\
\hline & & -10 & 1.094 & 5.40 & 127.58 & 55.85 & 74.85 & 7.18 & 0.31 & 1.30 & 0.75 & 0.24 \\
\hline & $\operatorname{Mean}^{(2)}$ & & $1.252 \mathrm{~A}$ & $6.18 \mathrm{~B}$ & $134.85 \mathrm{~B}$ & $63.26 \mathrm{~A}$ & $81.64 \mathrm{~A}$ & $7.58 \mathrm{~A}$ & $0.26 \mathrm{~B}$ & $1.63 \mathrm{~A}$ & $0.87 \mathrm{~B}$ & $0.36 \mathrm{~B}$ \\
\hline \multirow[t]{7}{*}{$\mathrm{CCM}$} & Soil & -40 & 0.139 & 32.00 & 124.78 & 35.46 & 40.02 & 4.80 & 0.31 & 1.47 & 1.47 & 0.51 \\
\hline & & -10 & 0.134 & 29.49 & 130.10 & 22.49 & 25.48 & 5.94 & 0.43 & 0.52 & 0.80 & 1.18 \\
\hline & $\mathrm{AG}<0.5 \mathrm{~mm}$ & -40 & 0.144 & 37.88 & 153.07 & 19.89 & 26.51 & 10.80 & 0.31 & 0.74 & 3.06 & 1.48 \\
\hline & & -10 & 0.281 & 23.58 & 101.07 & 16.93 & 18.03 & 3.47 & 0.87 & 0.87 & 0.67 & 1.08 \\
\hline & $\mathrm{AG} 0.5-4.0 \mathrm{~mm}$ & -40 & 0.085 & 19.89 & 227.64 & 30.67 & 28.34 & 5.21 & 0.30 & 1.74 & 0.99 & 1.01 \\
\hline & & -10 & 0.129 & 39.35 & 156.43 & 38.46 & 42.05 & 7.08 & 0.48 & 1.41 & 2.04 & 1.70 \\
\hline & $\operatorname{Mean}^{(2)}$ & & $0.152 \mathrm{~B}$ & $30.36 \mathrm{~A}$ & $148.85 \mathrm{~A}$ & 27.31B & $30.07 \mathrm{~B}$ & $6.22 \mathrm{~A}$ & $0.33 \mathrm{~A}$ & $1.12 \mathrm{~B}$ & $1.50 \mathrm{~A}$ & $1.16 \mathrm{~A}$ \\
\hline
\end{tabular}

(1) Natural Cerradão vegetation (CER) and continuous maize under conventional management (CCM). ${ }^{(2)}$ Different letters in column indicate differences at $1 \%$ by the $\mathrm{F}$ test for management system. 
MCC, were 2.71, 1.65, 7.04, 6.18 and 0.64, for P, K, $\mathrm{Ca}, \mathrm{Mg}$ and S, respectively (Table 3 ). The appreciable difference in the concentrations in soil solution $\mathrm{Ca}$ and $\mathrm{Mg}$ allowed higher concentration of these nutrients in the exudate removed from plants grown in CER soil samples. In the case of $\mathrm{P}$ and $\mathrm{K}$, similar concentrations and significantly lower exudate volumes in plants grown on samples of the CCM increased the concentration of these elements. In relation to $\mathrm{S}$, the lower concentration in the system CER was compensated by a higher exudate volume, without statistical differences between the two management systems. For the micronutrients, the low concentrations in soil solution indicate that the absorption of these elements responded more to metabolic than osmotic effects, leading to different values (Table 5).

Based on the mean nutrient concentration in the xylem sap (Table 5) and the concentration in soil solution (Table 3), the relationship between these two variables was calculated. The values were $487.9(\mathrm{P})$, $30.1(\mathrm{~K}), 5.7(\mathrm{~S}), 4.5(\mathrm{Mg})$ and $0.7(\mathrm{Ca})$ in samples of the CER system. In addition, diffusion was responsible for the transport of 99.5, 84.8, 60.3, 29.7 and $0 \%$ of these nutrients, respectively. Considering that root pressure is a consequence of factors involved in metabolic (active absorption) and osmotic processes (concentration gradient) (Zholkevich, 1991), the conclusion could be drawn that the higher the contribution to transport by diffusion, the greater the participation of metabolic processes in the plant nutrient uptake.

Similar calculations were performed for samples of the CCM system, where the values for the relationship between concentrations were: 6,072 (P), $54.7(\mathrm{~K}), 10.3(\mathrm{Mg}), 3.0(\mathrm{~S})$ and $2.2(\mathrm{Ca})$. Since diffusion was responsible for transporting $99.8(\mathrm{P}), 94.8(\mathrm{~K})$, $49.5(\mathrm{~S}), 43.3(\mathrm{Mg})$, and $2.4 \%(\mathrm{Ca})$, there is an inverted sequence in the comparison of $\mathrm{Mg}$ and $\mathrm{S}$.

Analyzing the effect of aggregate size $\left(\mathrm{C}_{2}:-1.00^{* *}\right)$, it appears that the largest exudate volume was collected from plants grown in aggregates $<0.5 \mathrm{~mm}$ in the CER system only. This result was due to the higher water availability in these than in larger aggregates (Table1). The exudate volume collected from maize plants was influenced by water availability $\left(\mathrm{C}_{3}: 1.47^{* *}, \mathrm{C}_{4}: 1.21^{* *}\right.$ and $\left.\mathrm{C}_{5}: 0.93^{* *}\right)$ in CER soil only. This result demonstrates the strong dependence of the exudate volume on the soil water potential (Table 5).

\section{CONCLUSIONS}

1. A greater nutrient availability resulted in increased mass flow and diffusion transport of N, Ca, $\mathrm{Mg}, \mathrm{S}, \mathrm{P}, \mathrm{Fe}, \mathrm{Mn}, \mathrm{Zn}$, and $\mathrm{Cu}$ to the roots in a comparison of natural Cerradão vegetation (CER) with continuous maize in a conventional system for more than 30 years (CCM).
2. The proportion of mass flow contribution to nutrient transport was the following: $\mathrm{Ca}>\mathrm{Mg}>\mathrm{N}>$ $\mathrm{S}>\mathrm{K}>\mathrm{P} \approx \mathrm{Mn} \approx \mathrm{Zn} \approx \mathrm{Cu} \approx \mathrm{Fe}$. The mean values for the first five were $100,63,56,45$ and $10 \%$ respectively.

3. The diffusion was the main mechanism of $K, P$, $\mathrm{Fe}, \mathrm{Mn}, \mathrm{Zn}$, and $\mathrm{Cu}$ transport, accounting for values above $99 \%$ except for $\mathrm{K}$, where the value was $90 \%$.

4. The influence of aggregate size and soil water potential is higher in soil samples with higher soil solution nutrient concentrations.

5. The xylem exudate volume increases with a reduced aggregate size and increased soil water availability. The nutrient concentration in the xylem exudate is higher than in soil solution, with exception of $\mathrm{Ca}$.

\section{LITERATURE CITED}

AL-ABBAS, H. \& BARBER, S.A. Effects of root growth and mass-flow on the availability of soil calcium and magnesium to soybeans in a greenhouse experiment. Soil Sci., 97:103-107,1964.

ALVAREZ V., V.H. \& ALVAREZ, G.A.M. Comparação de médias ou teste de hipóteses? Contrastes! B. Inf. SBCS, 31:24-34, 2006.

ARAÚJO, C.A.S.; RUIZ, H.A.; SILVA, D.J.; FERREIRA, P.A.; ALVAREZ V., V.H. \& BAHIA FILHO, A.F.C. Eluição de magnésio, cálcio e potássio de acordo com o tempo de difusão em colunas com agregados de um Latossolo Vermelho distrófico típico. R. Bras. Ci. Solo, 27:231-238, 2003 .

BARBER, S.A. A diffusion and mass-flow concept of soil nutrient availability. Soil Sci., 93:39-49, 1962.

BARBER, S.A. Influence of the plant root on ion movement in soil. In: CARSON, E.W., ed. The plant root and its environment. Charlottesville, University Press of Virginia, 1974. p.525-564.

BARBER, S.A. Soil nutrient bioavailability: A mechanistic approach. New York, John Wiley, 1984. 398p.

BARROS, N.F. \& COMERFORD, N.B. Sustentabilidade da produção de florestas plantadas na região tropical. In: ALVAREZ V., V.H.; SCHAEFER, C.E.G.R.; BARROS, N.F.; MELLO, J.W.V. \& COSTA, L.M., eds. Tópicos em ciência do solo. Viçosa, MG, Sociedade Brasileira em Ciência do Solo, 2002. v.2. p.487-592.

BRAGA, J.M. \& DEFELIPO, B.V. Determinação espectrofotométrica de fósforo em extratos de solos e plantas. R. Ceres, 21:73-85, 1974.

COSTA, L.C.; MORISON, J. \& DENNETT, M. Effects of water stress on photosynthesis, respiration and growth of Faba bean (Vicia faba L.) growing under field conditions. R. Bras. Agron., 5:9-16, 1997. 
DEFELIPO, B.V. \& RIBEIRO, A.C. Análise química de solo. Viçosa, MG, Universidade Federal de Viçosa, 1981. 17p. (Boletim de Extensão)

EMPRESA BRASILEIRA DE PESQUISA AGROPECUÁRIA EMBRAPA. Centro Nacional de Pesquisa de Solos. Manual de métodos de análise de solo. 2.ed. Rio de Janeiro, Centro Nacional de Pesquisa de Solos, 1997. 212p.

FERNANDES, M.S. Nutrição mineral de plantas. Viçosa, MG, Sociedade Brasileira de Ciência do Solo, 2006. 432p.

HILLEL, D. Soil and water. Physical principles and processes. New York, Academic Press, 1971. 288p.

KEMPERS, A.J. \& ZWEERS, A. Ammonium determination in soil extracts by the salicylate method. Comm. Soil Sci. Plant. Anal., 17:715-723, 1986.

LARCHER, W. Ecofisiologia vegetal. São Carlos, RiMa, 2000. $531 \mathrm{p}$.

MARSCHNER, H. Mineral nutrition of higher plants. 2.ed. London, Academic Press, 1995. 889p.

NOVAIS, R.F. \& SMYTH, T.J. Fósforo em solo e planta em condições tropicais. Viçosa, MG, Universidade Federal de Viçosa, 1999. 399p.

NUMES, F.N.; NOVAIS, R.F.; SILVA, I.R.; GEBRIM, F.O. \& SÃO JOSÉ, J.F.B. Fluxo difusivo de ferro em solos sob influência de doses de fósforo e de níveis de acidez e umidade. R. Bras. Ci. Solo, 28: 423-430, 2004.

NYE, P.H. \& TINKER, P.B. Solute movement in the soil-root system. Berkeley, University of California Press, 1977. $342 \mathrm{p}$.

OLIVEIRA, R.H.; ROSOLEM, C.A. \& TRIGUEIRO, R.M. Importância do fluxo de massa e da difusão no suprimento de potássio ao algodoeiro como variável de água e potássio no solo. R. Bras. Ci. Solo, 28:439-445, 2004.

OKAJIMA, H. \& TANIYAMA, I. Significance of mass flow in nitrate-nitrogen supply to plant roots. Soil Sci. Plant Nutr., 26:363-374, 1980.
ROSOLEM, C.A.; MATEUS, G.P.; GODOY, L.J.G.; FELTRAN, J.C. \& BRANCALIÃO, S.R. Morfologia radicular e suprimento de potássio ás raízes de milheto de acordo com a disponibilidade de água e potássio. R. Bras. Ci. Solo, 27:875-884, 2003.

RUIZ, H.A. Incremento da exatidão da análise granulométrica do solo por meio da coleta da suspensão (silte + argila). R. Bras. Ci. Solo, 29:297-300, 2005.

RUIZ, H.A.; MIRANDA, J. \& CONCEIÇÃO, J.C.S. Contribuição dos mecanismos de fluxo de massa e de difusão para o suprimento de $\mathrm{K}, \mathrm{Ca}$ e $\mathrm{Mg}$ a plantas de arroz. R. Bras. Ci. Solo, 23:1015-1018, 1999.

STREBEL, O. \& DUYNISVELD, W.H.M. Nitrogen supply to cereals and sugar beet by mass flow and diffusion on silty loam soil. Z. Pflanzenernährung. Bodenk., 152:135-141, 1989.

VALE, F.R.; NOVAIS, R.F.; SANT'ANNA, R. \& BARROS, N.F. Absorção e translocação de fosfato em milho suprido com nitrato ou amônio e pré-tratado com alumínio. R. Bras. Ci. Solo, 8:219-222, 1984.

VARGAS, R.M.B.; MEURER, E.J. \& ANGHINONI, I. Mecanismos de suprimento de fósforo, potássio, cálcio e magnésio às raízes de milho em solos do Rio Grande do Sul. R. Bras. Ci. Solo, 7:143-148, 1983.

WILD, A. Mass flow and diffusion. In: GREENLAND, D.J. \& HAYES, M.H.B., eds. The chemistry of soil processes. Chichester, John Wiley, 1981. p.37-80.

YANG, J.E.; SLOGLEY, E.O.; SCHAFF, B.E. \& KIM, J.J.A. Simple spectrophotometric determination of nitrate in water, resin and soil extracts. Soil Soc. Am. J., 62:1108$1115,1998$.

YEOMANS, J.C. \& BREMNER, J.M. A rapid and precise method for routine determination of carbon in soil. Comm. Soil Sci. Plant Anal., 19:1467-1476, 1988.

ZHOLKEVICH, V.N. Root pressure. In: WAISEL, Y.; ESHEL, A. \& KAFKAFI, U., eds. Plant roots: The hidden half. New York, Marcel Dekker, 1991. p.589-603. 
